\title{
Christian Martyrs Under Islam: Religious Violence and the Making of the Muslim World
}

\author{
Christian C. Sahner \\ Princeton: Princeton University Press, 2018. 360 pages.
}

The study of Christian martyrdom in the early Islamic world can be situated within the wider study of the Islamization of the Middle East, and by extension, Muslim-Christian relations. Similar works pertaining to this 
field are Richard Bulliet's Conversion to Islam in the Medieval Period: An Essay in Quantitative History (1979) and Fred Donner's Narratives of Islamic Origins: The Beginnings of Islamic Historical Writing (1998). Christian Sahner's Christian Martyrs Under Islam attempts the first holistic account of Christian martyrs in Islam's early history (the seventh to the ninth centuries) alongside investigating the role violence played in shaping Islamic dominance within the region. The prominent use of Christian hagiography may leave readers wary of the book's reliance on potentially hostile sources, but he uses a diverse array of empirical evidence, of both Muslim and Christian origin, while emphasizing the limited Muslim sources connected to martyrology. Methodologically, he employs an approach of "critical positivism", balancing "literalism and skepticism" (11) in order to elevate non-Muslim sources which may otherwise have been delegitimized. This constructs an alternative historical account of the Muslim world's maturation from a non-Muslim viewpoint.

Sahner introduces the term "new martyr" (2), differentiating Christian martyrs of the pre-Islamic era (such as those within the Sasanian empire) from those celebrated by Christians as contemporary, 'new' martyrs in the formative centuries of Islamic rule. He also nods to the argument for a general historical continuity between Late Antiquity and the Islamic era, as opposed to marking Islam as a point of historical rupture. This varied group of "new martyrs," roughly 270 martyrs and saints, was accompanied by the spreading of individual cults. The small size of this group undermines the notion that Islamic authorities systematically and routinely weaponized violence in their governance. Instead Sahner emphasizes the state's relatively indifferent approach to dhimmìs.

Chapter one focuses on Christians who converted to Islam and later reverted back to Christianity, particularly on their spiritual and social experiences. This phenomenon of double apostasy points to the fluidity of the era, which lacked a firm border between "religious conversion and cultural assimilation" (33). The Islamization of the region following the conquests of the seventh century was not as linear as perceived by later scholars. The grey areas of these evolving religious and social norms were further exemplified through religiously mixed families, within which both Christianity and Islam were practiced. Sahner considers the importance of outward appearance and sartorial practices, as in the "accidental conversion" of Elias of Helioupolis when he removed his belt (zunnār). The "gap between action 
and belief in early converts" (52) hints at the practice of early Islam being more loosely defined, compared to later orthodoxy.

Within this broader apostate group, chapter two focuses on "true apostates", or Christian converts originally hailing from Muslim backgrounds, constituting a rare but significant group. Despite the limited relevant Muslim and Christian sources, the examples of martyrs such as David of Dwin and Abo of Tiflis show such conversions occurring at the outliers of the caliphate, where Christians were the hegemonic group. Regardless of the target religion, social and political reasons are clearly factors in conversion. This allows readers to better understand the powerful stream of mass conversions to Islam which occurred in the seventh, eighth, and ninth centuries.

Coupled with apostasy, blasphemy was another leading cause of martyrdom. Chapter three discusses the reasoning and social context of blasphemers, particularly in al-Andalus: fast-paced demographic transformation, cultural divides between Muslims and Christians living in close proximity, and the lack of religious segregation enforced through garrison cities. These factors, including the growth of the Muslim scholarly class, led to heightened tensions and solidifying boundaries of Islamic orthodoxy, encouraging some Christians-also referred to as "cultural apostates" (149) - to invoke blasphemy as a "theological protest" (119). Sahner affirms the usefulness of martyrology in determining how Islamic judicial processes and Abrahamic intellectual thought developed, as blasphemy laws were slow to crystallize in the early period (120). A sophisticated and reactionary anti-Muslim polemic in the mid-ninth century onwards accompanied the rise of blasphemers.

Judicial developments reveal much about a state's structure and the priority it affords to various spheres of ruler-subject dispute. In chapter four, Sahner delves into judicial rulings on apostasy and blasphemy as well as the rationales behind these criminal punishments. He examines the course of the martyr within the legal system: from a trial, to the articulation of a punishment derived from Islamic scripture (through which an early culture of blasphemy law evolved), to the punishments themselves. The execution of Christian apostates and blasphemers in the Umayyad and Abbasid eras was attributed to the necessity of asserting Islamic legitimacy, among "numerically dominant" (161) Christian subjects, by utilizing state-sanctioned disciplinary violence. Sahner asserts that executions also occurred as a means of imposing and affirming Islamic identity, again within this broader polemical context. More generally, he emphasizes the 
integral role of forgiveness within the Islamic judicial treatment of apostates and blasphemers, as when Peter of Capitolias was afforded multiple offers of clemency.

The fifth chapter examines the narrative work of hagiographies and their goals beyond mere biography. Here the reader is presented with the demographic contrast between assimilated urban clergy, who tended to adopt a more lenient attitude in their writings, as opposed to rural monks ("rejectionists," 27), who were more austere in their discourse and in condemning a distant faith they had little interaction with. Sahner also discusses hagiography's innate sectarian nature, referencing the dominance of the Melkites, "the Chalcedonian Christians who remained in communion with Constantinople after the Arab conquest" (225). Their production of the highest number of neo-martyr works and their links to Byzantium suggested their aversion to being subjected to a new elite, alongside their own political and religious decline. This resulted in martyrdom becoming enshrined within Melkite (as opposed to Nestorian or Miaphysite) hagiographical discourse as a component of a wider conversation on resistance to Islamic encroachment.

The confluence of various anxieties is mapped out by the book's concluding chapter. Whereas in the immediate post-conquest era, Islamic rule was punctuated by lower levels of violence (for government was mainly concerned with the maintenance of order and taxation), the Islamizing campaign of 'Abd al-Malik in the late seventh and early eighth centuries heightened awareness of religious variance. Martyrs were used to legitimize Christianity's place in society, through enforcing their examples as symbols of Christian agency. Sahner traces the decline of new martyr cults after the tenth century. Christian intellectual thought turned to theological disputes rather than martyrology, admitting Islam's enduring presence in the socio-political arena. Briefly touching on comparative Christian and Shīi $\overline{1}$ martyrologies, a promising site for future inquiry, Sahner underscores the role of martyrs played in "delimit(ing) and fortif(ying) borders of community" (251), thus preserving Christian authority under Muslim rule.

Sahner combs through a variety of sources in order to present an intricate and informative illustration of martyrs' lives, and their subsequent historical, social and religious symbolism within the Muslim world. Given the rare mention of neo-martyrs in Muslim accounts, Sahner critically engages and closely reads the available sources (largely Christian hagiographies). He underscores any likely anti-Muslim biases and highlights 
strengths when credible. By reading these sources against the grain, Sahner gleans more from them than mere chronology. He imaginatively discusses the individual intricacies of each martyr's life and asks questions pertaining to the spiritual, economic, political, and cultural context of the medieval Islamic world. Sahner also succinctly indicates academic lacunae in relation to martyrology, such as the evolution of Islamic jurisprudence and early Islamic social history, as prospective areas to be investigated.

Tayyaba Rafiq MPhil Islamic Studies and History University of Oxford, Oxford, UK

doi: 10.35632/ajiss.v37i1-2.719 